\title{
KAJIAN LAPANGAN MENINGKATKAN KEMAHIRAN PEDAGOGI GURU SEJARAH: STUDI KASUS DI TAPAK ARKEOLOGI LEMBAH BUJANG DAN SUNGAI BATU
}

\author{
Punitha Muniandy \\ Jabatan Penyelidikan dan Inovasi Profesionalisme Keguruan, IPGK Tuanku Bainun, Malaysia \\ Email: punithaipgktb@gmail.com
}

Nagamah Marimuthu

Unit Sejarah, Jabatan Sains Sosial' IPG Kampus Tuanku Bainun, Malaysia

Email: nagama18@gmail.com

\author{
Abdul Rahim Ali \\ Unit Sejarah, Jabatan Sains Sosial' IPG Kampus Tuanku Bainun, Malaysia \\ Email: rahimk.kbb@gmail.com
}

\section{Sivarajan Ponniah}

Unit Sejarah, Jabatan Sains Sosial' IPG Kampus Tuanku Bainun, Malaysia

Email: sivamptb@hotmail.com

\section{Zahari Zainal}

Unit Sejarah, Jabatan Sains Sosial' IPG Kampus Tuanku Bainun, Malaysia

Email:zaha2000pp@hotmail.com

\section{Ravendran Chelliah}

Unit Sejarah, Jabatan Sains Sosial, IPG Kampus Tuanku Bainun, Malaysia

\section{Jefriza}

Departemen Teknik Lingkungan, Universitas Serambi Mekkah, Aceh, Indonesia

\begin{abstract}
Abstrak
Penelitian dilakukan terhadap 40 guru yang mengajar sejarah di_Sekolah Dasar Seberang Prai Tengah, Penang. Tujuan dari penelitian ini adalah untuk mengevaluasi efektifitas penelitian lapangan dalam meningkatkan kualitas keterampilan pedagogis guru Sejarah. Sebanyak 40 guru sejarah 20 di antaranya adalah perempuan dan 20 laki-laki lainnya dari Sekolah Menengah Seberang Prai Tengah dipilih sebagai responden untuk penelitian ini. Aspek penelitian yang diamati adalah penggunaan penelitian lapangan, pengetahuan atau informasi yang diperoleh dari penelitian lapangan, perasaan guru setelah melakukan penelitian lapangan dan efek dari program penelitian lapangan. Studi kasus di_lokasi arkeologi Lembah Bujang dan Sungai Batu, Kedah dilakukan untuk mengetahui pentingnya kelangsungan penelitian. Analisis deskriptif dan uji t digunakan. Selanjutnya, wawancara dan metode observasi digunakan pada peserta penelitian untuk memperkuat temuan penelitian. Hasil analisis menunjukkan aspek penelitian yaitu penggunaan penelitian lapangan, pengetahuan atau informasi yang diperoleh dari penelitian lapangan, perasaan guru setelah melakukan penelitian lapangan,dan pengaruh program penelitian lapangan di_situs arkeologi Lembah Bujang dan Sungai Batu di_antara guru sejarah SMA tidak signifikan. Namun, skor rata-rata yang terkait dengan dampak program penelitian lapangan di_situs arkeologi Lembah Bujang dan Sungai Batu menunjukkan bahwa guru laki-laki memiliki hubungan yang jauh lebih menyenangkan dan lebih tertarik dalam kegiatan belajar mengajar dibandingkan dengan guru perempuan.
\end{abstract}

Kata kunci: Meningkatkan, Kemahiran Pedagogi, Guru Sejarah 


\begin{abstract}
Research was carried upon 40 teachers who teach historyat Sekolah Menengah Seberang Prai Tengah, Penang. The purpose of the study is to evaluate the efectiveness of field research in increasing the quality of a History teachers pedagogical skills. As many as $\mathbf{4 0}$ history teachers of whom 20 were female and the other 20 male from Sekolah Menengah Seberang Prai Tengah were chosen as respondents for the research. The research aspect which was observed is the usage of field research, knowledge or informationgained from field research, the feeling of the teacher after carrying out the field research and the effect of thefield research programme. Thecase study at the archeological site of Lembah Bujang and Sungai Batu, Kedah was carried out to observe the significanceof the research continuity. A descriptive analysis and a t-test were used. Furthermore, the interview and the observation methods were used upon the researchparticipants to strengthen the research findings. Analysis results indicate the research aspect which is the usage of field research, knowledge or informationgained from field research, the feeling of the teacher after carrying out the field research and the effect of thefield research programme at the archeological site of Lembah Bujang and Sungai Batu amongst the high school history teachers are not significant, however, the mean score related to the effect of thefield researchprogramme at the archeological site of Lembah Bujang and Sungai Batu shows that the male teachers had a much more fun engangementand are more interested in the teaching and learning activities compared to the female teachers.
\end{abstract}

Keywords:Improve, Pedagogy Proficiency, Teacher, History

\section{PENDAHULUAN}

Penelitian lapangan merupakan suatu metode pendekatan yang memberi penilaian yang besar dalam pengajaran dan pembelajaran sejarah. Penelitian ini merupakanpenelitian kualitatif dan pengamatan dilakukan secara langsung dari bahan yang dipelajari (Neuman, 2003). Mengikut Spradly (1980), Van Maanen (1988) dan Agar (1996) faktor pengamatan dan partisipasipeserta memainkan peran utama dalam menjalankan aktivitas penelitian lapangan. Partisipasi peserta akan membuahkan hasil yang baik bila peserta sendiri menjadi bagian dari penelitian itu sendiri. Seringkali seorang guru hanya menjadi 'non-participant atau tidak meletakkan dirinya sendiri sebagai peneliti untuk memperkuat ilmu pengetahuannya mengenai suatu judul atau topik. Ilmu pengetahuan didalami hanya melalui pembacaan, suratkabar, majalah atau media massa.

$$
\text { Penelitian lapangan juga }
$$

merupakan metode penting dalam usaha memberi pemaparan kepada guru-guru untuk menjadikan alam sebagai sebuah laboratorium untuk menerangkan ciriciri fisik, manusia dan hubungan dengan lingkungan terhadap murid-murid di_sekolah (Wan Ruslan, Narimah Samat dan Nooriah Yusof, 2014). Partisipasi aktif yang melibatkan aspek emosi peserta dalam mendapatkan ilmu berkaitan dengan topik yang diajarnya juga dapat memantapkan lagi penguasaannya ke atas topik sejarah terutama berkaitan dengan kerajaankerajaan pra-sejarah yang merupakan judul utama bagi pembelajaran sejarah. 
Pendidikan Malaysia menjadikan mata pelajaran sejarah sebagai mata pelajaran inti yang wajib dipelajari semua murid pada tahap II pembelajaran, yaitu mulai tahun ke-4. Kurikulum Standar Sekolah Dasar mata pelajaran Sejarah mendukung cita-cita murni menyediakan kurikulum yang relevan dan terkini ke arah memperkembangkan potensi individu Malaysia yang baik dari segi rohani, jasmani, intelektual dan emosi. Untuk mencapai tujuan pendidikan negara, penekanan diberikan kepada domain kognitif, afektif dan psikomotorserta elemen nilai tambah alat baru seperti kemahiran berpikir, kemahiran teknologi informasi, dan komunikasi, kemahiran berbagai kecerdasan, penelitian masa depan dan pembelajaran sepanjang hidup. Kurikulum ini juga memberi penekanan kepada penerapan nilai-nilai murni, semangat patriotik, elemen kewarganegaraan dan masyarakat. Zaman Pra sejarah merupakan topik pengenalan yang utama bagi muridmurid untuk mengenali sejarah tanah airnya. Situs-situs arkeologi dan penemuan-penemuan yang berkaitan merupakan katalisator dalam membentuk kognitif dan afektif murid untuk meminati mata pelajaran sejarah selanjutnya.

Pemilihan dan penyelidikan situs arkeologi dijalankan menggunakan metode ilmiah terkini yang melintasi berbagaidisiplin ilmu. Gabungan ilmu antropologi, sejarah, geografi, fisika, geofisika, kimia dan juga teknologi informasi dan komunikasi akan memantapkan lagi pengalaman dan pengetahuan berkaitan teknik analisis dan permodelan situs penelitian. Walaupun melibatkan gabungan berbagai disipilin, penelitian arkeologi ternyata mempunyai data, teknik dan konsepnya yang tersendiri. Penyatuan berbagai bidang penelitian yang merentasi penguasaan ilmu sejarah merupakan satu keunikan yang wajib dikuasai oleh warga pendidik dalam meningkatkan penguasaan sejarah dan kaedah penyampaian'hands on boleh dikagumi pelajar untuk meningkatkan partisipasi dalam pembelajaran sejarah. Penerbitan An Account of several inscriptions found in Province Wellesly in Peninsula of Malacca dan On an Inscription of Kedah oleh James Low pada tahun 1948 merupakan titik permulaan bagi penelitiansitusdan artefak arkeologi negara Malaysia(Tarmiji dan Mokhtar, 2013). Sejak dari penulisan James Low tersebut, banyak lagi situs-situs arkeologi ditemui dan berbedabedamengikut distribusidan bentuk fisiknya.

Pengungkapan terhadap penelitian lapangan dalam diri guru-guru sejarah adalah langkah utama bagi mencapai tujuan pendidikan Malaysia. Sekelompok 
guru-guru sejarah sekolah menengah sebanyak 40 orang dilibatkan secara langsung dalam mempelajari metode dan teknik membuat penelitian lapangan di_situs arkeologi Sungai Batu dan situs arkeologi Lembah Bujang di_negeri Kedah. Kedua-dua situs tersebut ternyata pusat penelitian situs arkeologi yang terkenal di Malaysia. Situs arkeologi Lembah Bujang pula terletak di dua lembangan sungai yaituSungai Merbok dan Sungai Muda. Pangkalan Bujang dan Sungai Emas merupakan dua situs arkeologi yang sangat jelas dengan situs yangluas dan kependudukan yang pusat di_zaman Kedah Tua. Situs arkeologi Sungai Batu merupakan situs baru yang ditemui di_kawasan Sungai Batu oleh Pusat Penyelidikan arkeologi Global (PPAG), Universiti Sains Malaysia. Situs ini diiktiraf sebagai situs tertua di_rantau ini yang digunakan sejak abad Ke-5 masihi dengan penemuan 97 situs yang melibatkan situs ritual, situs administrasi, situs dermaga dan situs peleburan bijih besi.

Penelitian lapangan kelompok
guru-guru tersebut bertujuan mengeksplorasi kedudukan dan peranan situs arkeologi Sungai Batu dan situs arkeologi Lembah Bujang tersebut pada zamannya. Penelitian lapangan mampu membawa perubahan besar dalam menabur pengetahuan, kemahiran dan nilai sejarah di_kalangan guru-guru.
Kemahiran guru juga meningkat dalam melaksanakan pengajaran dan pembelajaran sejarah secara kreatif dan inovatif yang seterusnya dapat memupuk minat untuk membelajari subjek sejarah dengan lebih berkesan. Pengajaran sejarah yang menyelitkan pendekatan, metode, teknik dan aktivitas-aktivitas yang menarik dan inovatif dapat menghidupkan mata pelajaran sejarah.

Oleh yang demikian, penguasaan ilmu secara penelitian lapangan oleh guru berupaya memotong isu dan permasalahan dalam proses pengajaran dan pembelajaran sejarah. Penguasaan ilmu yang mantap dalam topik-topik tertentu oleh guru mampu meningkatkan keterlibatan murid dalam mata pelajaran sejarah. Penyampaian ilmu yang berkesan merupakan kelebihan guru dalam menabur sikap mencintai mata pelajaran sejarah yang ternyata dianggap membosankan dan juga sebagai 'mata pelajaran yang menghafal (Noria Munirah Yakub dan Anuar Ahmad, 2016). Mata pelajaran sejarah sering kali digambarkan sebagai mata pelajaran yang amat membosankan dengan fakta, kronologi dan kisah-kisah pergolakan masa lampau. Selain itu, guru sejarah juga dianggap sering menggunakan metode khutbah atau kuliah dan proses pengajaran dan pembelajaran sejarah. Dalam kebanyakan situasi murid hanya 
fokus pada menyalin catatan dan mendengar penjelasan guru saja. Situasi demikian membawa pelajaran sejarah secara tradisional dan satu arah yang membosankan dan tidak memberi ruang untuk peningkatan penguasaan sejarah yang sebenarnya dalam kalangan pelajar (Subadrah Nair dan Malar Muthiah, 2005)

Pendidikan abad ke 21 juga menekankan penggunaan kaedahkaedah pengajaran yang lebih dinamik, kreatif dan inovatif dengan kandungan pengajaran yang relevan dengan perkembangan transformasi pendidikan saat ini. Para guru perlu siap menerima perubahan dan dapat mengurus perubahan dengan efisien dan efektif agar proses belajar mengajar menjadi lebih segar dan memenuhi keperluan murid. Penekanan diberikan kepada penguasaan isi pelajaran sejarah dan efektivitas pelajaransejarah bergantung kepada pendekatan dan metode yang memberi peluang kepada murid-murid untuk melihat, memahami, menghayati dan seterusnya mengaplikasikan dalam kehidupannya kelak.

Bagi mensukseskan transformasi pendidikan yang diinginkan oleh negara Malaysia, pembelajaran yang berpusatkan kepada pelajar dengan menggunakan metode-metode pengajaran dan pembelajaran yang yang menarik dan inovatif perlu diutamakan dalam penyampaian ilmu sejarah. Dokumen Standar Kurikulum dan
Pentaksiran (DSKP) sejarah juga menekankan elemen - elemen kreatif dan inovatif bagi menanam minat murid terhadap mata pelajaran sejarah (Kementerian Pendidikan Malaysia, 2014). Elemen pendidikan yang kreatif dan inovatif memantapkan lagi pengajaran dan pembelajaran sejarah yang ternyata diberi stigma sebagai mata pelajaran pasif. Penelitian lapangan sedemikian berupaya mengubah pemikiran guru dalam pengusaaan isi kandungan sejarah dan juga penggunaan metode dan teknik penyampaian ilmu yang lebih bermakna di_samping melahirkan perasaancintakan negara meneruskan zaman-zaman pra- sejarahtelah memberi satu identitas unggul kepada sejarah negara. Penelitian lapangan dianggap sebagai satu aktifitas pengajaran dan pembelajaran yang dapat meningkatkan kemahiran kognitif dan afektif guru dan juga murid.

\section{METODE PENELITIAN}

Penelitian ini bertujuan untuk menilai efektifitas program penelitian lapangan dalam meningkatkan kemahiran pedagogi sejarah dalam kalangan guru-guru sejarah. Penelitian lapangan ini melibatkan penggunaan sumber pertama yaitu sumber arkeologi. Oleh itu penelitian lapangan dijalankan di_situs Arkeologi Lembah Bujang dan Situs Arkeologi Sungai Batu di_negeri 
Kedah. Sebanyak 40 orang guru mata pelajaran sejarah yang melibatkan 20 orang guru wanita dan 20 orang guru laki-laki sekolah menengah sekitar kawasan Seberang Prai Tengah, Negeri Pulau Pinang telah dipilih untuk penelitian lapangan ini dibawah program Petualangan Sejarah anjuran Institut Pendidikan Guru Kampus Tuanku Bainun dengan kerja sama Pejabat Pendidikan Daerah Seberang Prai Tengah. Program ini bertujuan memberi pendedahan tentang pengendalian Program Petualangan Sejarah di_sekolah, memberi pengalaman tentang penelitian lapangan, meningkatkanpengalaman guru tentang latar belakang setempat dan sejarahnya serta meningkatkan kemahiran pedagogi guru sejarah. Penelitian ini mengkaji keberkesanan program penelitian lapangan dalam meningkatkan domain kognitif dan afektif guru-guru sejarah sekolah menengah.

Berdasarkan tujuan tersebut satu set kuesioner digunakan sebagai instrumen dalam menentukan efektifitas program penelitian lapangan dalam meningkatkan domain kognitif dan afektif guru-guru sejarah sekolah menengah. Instrumen kuesioner tersebut terdiri daripada 27 item dalam 4 bagian yang berbeda. Kuesioner dibuat berdasarkan penelitian oleh Boyle et. al, (2007) berkenaan 'Kelebihan Penelitian Lapangan. Namun kuesioner penelitian ini diperbaharui berdasarkan keperluan penelitianberdasarkanbeberapa aspek yaitu kegunaan penelitianlapangan, pengetahuan dari penelitianlapangan, perasaan guru setelahmelakukan penelitianlapangan dan efekdaripada PenelitianLapangan.

Kuesioner ini diedarkan kepada guru-guru sejarah sekolah menengah yang terlibat dalam Program Petualangan Sejarah. Item-item di_dalam kuesioner tersebut diurutkanberdasarkan kelas mengikut 4 bagian dimana, bagian A terdiri dari 5 item, bagian B terdiri dari 4 item, bagian $C$ terdiri dari 10 item dan bagian D terdiri dari 8 item. Item-item dalam bagian A melibatkan kegunaan penelitian lapangan, bagian $B$ dengan pengetahuan dari penelitian lapangan, bagian $C$ perasaan setelah membuat penelitian lapangan dan bagian $D$ berdasarkan dari penelitian lapangan Situs Lembah Bujang dan Situs arkeologi Sungai Batu.

Penelitian ini menggunakan skala Likert 4 skala di_mana 1 mewakili "sangat tidak setuju", 2 mewakili "tidak setuju", 3 mewakili 'setuju" dan 4 mewakili "sangat setuju". Data dianalisis secara kuantitatif yaitu penggunaan SPSS versi 20. Antara analisis yang dijalankan adalah analisis deskriptif dan ujian $\mathrm{t}$ bagi melihat kesignifikanan kegunaan penelitian 
lapangan, pengetahuan daripada penelitian lapangan, perasaan guru setelah melakukan penelitian lapangan dan pengaruh dari Penelitian Lapangan Situs arkeologi Lembah Bujang dan Sungai Batu dalam kalangan guru-guru sejarah sekolah menengah. Di samping itu penelitian secara kualitatif juga telah dijalankan terhadap lima orang peserta penelitian bagi tujuan melihat efektivitas program penelitian lapangan setelah menyertai program petualangan sejarah.

\section{Analisis data kuantitatif}

Penelitian dijalankan terhadap guru-guru Sejarah Sekolah Menengah sekitar kawasan Seberang Perai Tengah, Pulau Pinang. Guru-guru sejarah telah diberi informasi sebelum perjalanan ke situs arkeologi Lembah Bujang dan Sungai Batu. Penelitian dijalankan bagi melihat hubungan jenis kelamin dengan parameter seperti berikut yang masingmasing mempunyai ketepatan yang tinggi dengan mencatat nilai Cronbach's Alpha bagi kegunaan penelitian lapangan (.906), pengetahuan dari penelitian lapangan (.917), perasaan setelah penelitian lapangan (.549) dan kesan daripada program penelitian lapangan (.968). Analisis terhadap setiap variabel penelitian menunjukkan cronbach's Alpha yang tinggi. Analisis kuesioner telah digunakan bagi menafsirkan data secara kuantitatif. Sebanyak 40 responden guru-guru sekolahmenengah yang terdiri dari guru laki-laki dan perempuan telah diberi respon masing-masing.

Analisis uji-t untuk sampel-sampel bebas digunakan bagi melihat perbedaan yang signifikan antara guruguru laki-laki dan perempuan bagi keempat-empat variabel yaitu kegunaan penelitian lapangan, pengetahuan yang diperoleh dalam penelitian lapangan, kesan daripada penyertaan program penelitian lapangan dan perasaan setelah menyertai penelitian lapangan. Tabel 1 menunjukkan skor minimum bagi dua kelompok guru laki-laki dan perempuan yang menyertai penelitian lapangan.

Tabel 1: Nilai Rerata bagi Kelompok Guru Laki-laki dan Perempuan

\begin{tabular}{|l|l|l|l|r|r|}
\hline & Jenis kelamin & $\mathrm{N}$ & Mean & Std. Deviation & Std. Error Mean \\
\hline \multirow{2}{*}{ Kegunaan } & Laki-laki & 20 & 3.5200 & .41751 & .09336 \\
& Perempuan & 20 & 3.5200 & .43237 & .09668 \\
Pengetahuan & Laki-laki & 20 & 3.4375 & .44334 & .09913 \\
\hline
\end{tabular}


Kajian Lapangan Meningkatkan Kemahiran Pedagogi Guru Sejarah ..., Punitha Muniandy, 1-14

\begin{tabular}{|c|c|c|c|c|c|}
\hline & Perempuan & 20 & 3.4375 & .43585 & .09746 \\
\hline \multirow{2}{*}{ Efek } & Laki-laki & 20 & 3.4938 & .46502 & .10398 \\
\hline & Perempuan & 20 & 3.4875 & .40737 & .09109 \\
\hline \multirow{2}{*}{ Perasaan setelah } & Laki-laki & 20 & 2.7400 & .32184 & .07196 \\
\hline & Perempuan & 20 & 2.6550 & .16051 & .03589 \\
\hline
\end{tabular}

Berdasarkan Tabel 1, tidak dengan penelitian lapangan. Guru lakiterdapat perbedaanminimum yang laki menunjukkan perasaan yang lebih signifikan bagi variabel-variabel senang dalam bergabung dengan Kegunaan, Pengetahuan dan Efek dari penelitian lapangan dibandingkan penelitian lapangan. Namun nilai rerata guru laki-laki (rerata=2.74) adalah lebih tinggi berbanding skor rerata guru perempuan (rerata=2.65) yang menyatakan perasaan setelah bergabung

dengan guru-guru perempuan.

Analisis uji-t sampel-sampel bebas bagi keempat-empat variabel dapat dilihat dalam Tabel 2 di_bawah.

Tabel 2: Analisis Ujian-t

\begin{tabular}{|c|c|c|c|c|c|c|c|c|c|c|}
\hline & \multirow[t]{2}{*}{$\mathrm{F}$} & \multirow[t]{2}{*}{ Sig. } & \multirow[t]{2}{*}{$\mathrm{t}$} & \multirow[t]{2}{*}{$\mathrm{df}$} & \multirow{2}{*}{$\begin{array}{l}\text { Sig. } \\
(2- \\
\text { tailed } \\
)\end{array}$} & \multirow[t]{2}{*}{\begin{tabular}{|c} 
Mean \\
Differenc \\
$\mathrm{e}$
\end{tabular}} & \multirow{2}{*}{\begin{tabular}{c|} 
Std. \\
Error \\
Differe \\
nce
\end{tabular}} & \multicolumn{2}{|c|}{$\begin{array}{l}\text { 95\% Confidence } \\
\text { Interval of the } \\
\text { Difference }\end{array}$} \\
\hline & & & & & & & & & Lower & Upper \\
\hline Kegunaan & \begin{tabular}{|l|} 
Equal \\
variances \\
assumed
\end{tabular} & .090 & .766 & .000 & 38 & 1.000 & .00000 & .13440 & -.27208 & .27208 \\
\hline $\begin{array}{l}\text { Pengetahua } \\
\mathrm{n}\end{array}$ & $\begin{array}{l}\text { Equal } \\
\text { variances } \\
\text { assumed }\end{array}$ & .128 & .722 & .000 & 38 & 1.000 & .00000 & .13902 & -.28142 & .28142 \\
\hline Efek & \begin{tabular}{|l} 
Equal \\
variances \\
assumed \\
\end{tabular} & 3.625 & .064 & .045 & 38 & .964 & .00625 & .13824 & -.27360 & .28610 \\
\hline $\begin{array}{l}\text { Perasaan } \\
\text { setelah }\end{array}$ & $\begin{array}{l}\text { Equal } \\
\text { variances } \\
\text { assumed }\end{array}$ & 5.656 & .023 & 1.057 & 38 & .297 & .08500 & .08042 & -.07780 & .24780 \\
\hline
\end{tabular}

Analisis variabel kegunaan, keputusan ujian yang diperoleh adalah tidak signifikan ( $\mathrm{t}=0.00, \mathrm{df} 38, \mathrm{p}>.05)$. Tidak terdapat perbedaan antara kedua- dua kelompok guru laki-laki dan perempuan dari segi kegunaan penelitian lapangan. Nilai perbedaan rerata 0.000 menunjukkantidak adanya 
perbedaan yang signifikan dalam kepentingan penelitian lapangan bagi kedua-dua kelompok tersebut. Skor rerata bagi kedua-dua kelompok guru laki-laki (rerata=3.52) adalah sama dengan skor rerata guru perempuan (rerata $=3.52)$.

Analisis variabel pengetahuan, hasil tes yang diperoleh adalah tidak signifikan ( $t=0.00, d f 38, p>.05)$. Tidak terdapat perbedaan antara kedua-dua kelompok guru laki-laki dan perempuan dari segi pengetahuan yang diperolehi daripada penelitian lapangan. Nilai perbedaan rerata 0.000 menunjukkan tiada perbedaan yang signifikan dalam pengetahuan yang diperolehi daripada penelitian lapangan bagi kedua-dua kelompok tersebut. Skor rerata bagi kedua-dua kelompok guru laki-laki (rerata $=3.43$ ) adalah sama dengan skor rerata guru perempuan (rerata=3.43).

Analisis variabel kesan dari program penelitian lapangan, keputusan ujian yang diperoleh adalah tidak signifikan ( $t=0.45, d f 38, p>.05)$. Tidak terdapat perbedaan antara kedua-dua kelompok guru laki-laki dan perempuan dari aspek kesan daripada program penelitian lapangan. Nilai perbedaan rerata 0.006 menunjukkan tiada perbedaan yang signifikan dalam efek yang diperoleh dari penelitian lapangan bagi kedua-dua kelompok tersebut. Skor rerata bagi kedua-dua kelompok guru laki-laki (rerata=3.49) adalah sama dengan skor rerata guru perempuan (rerata $=3.49)$.

Analisis variabel perasaan setelah menyertai penelitian lapangan, hasil tes yang diperoleh juga adalah tidak signifikan ( $t=1.05, \mathrm{df} 38, \mathrm{p}>.05)$. Tidak terdapat perbedaan antara kedua-dua kelompok guru laki-laki dan perempuan dari aspek kesan daripada program penelitian lapangan. Nilai perbedaan rerata 0.85 menunjukkan tiada perbedaan yang signifikan dalam perasaan setelah mengikuti penelitian lapangan bagi kedua-dua kelompok tersebut. Skor rerata bagi kedua-dua kelompok guru laki-laki (rerata=3.74) terdapat sedikit perbedaan dengan skor rerata guru perempuan (rerata $=3.65$ ). Ini menunjukkan guru laki-laki mempunyai keterlibatan yang lebih menyenangkan, minat dan antusias terhadap aktivitas-aktivitas pengajaran dan pembelajaran luar bilik darjah.

\section{Analisis data kualitatif}

Penelitian kasus terhadap Program Petualangan Sejarah telah dipertanggung jawabkan untuk melihat sejauh mana pengaruh efektivitas penelitian lapangan dapat membantu meningkatkankemahiran pedagogi sejarah dalam kalangan guru-guru sejarah sekitar daerah Seberang Prai Tengah. Teknik utama yang digunakan yaitu tinjauan lapangan, dan juga 
wawancara yang dijalankan terhadap empat orang peserta Program Petualangan Sejarah.

Hasil analisa tinjauan lapangan menunjukkan penelitian lapangan memberi peluang kepada guru-guru, menyelami dan mempraktekan pembelajaran yang diperoleh. Guru-guru telah menunjukkan komitmen yang tinggi dari awal hingga akhir penelitian lapangan. Ini dapat dibuktikan dengan hasil-hasil presentasi yang hebat berdasarkan aktivitas-aktivitas sepanjang hari pertama program tersebut. Berdasarkan presentasi, menunjukkan guru lebih memahami dan bersedia untuk mempelajari ilmu sejarah serta menunjukkan minat yang tinggi. Hasil wawancara terhadap empat peserta menunjukkan hasil sebagai berikut:

Tabel 3: Hasil Wawancara Peserta Penelitian Lapangan

\begin{tabular}{|l|l|l|l|l|}
\hline & Peserta 1 & Peserta 2 & Peserta 3 & Peserta 4 \\
\hline $\begin{array}{l}\text { Kegunaan } \\
\text { penelitian }\end{array}$ & eksplorasi & $\begin{array}{l}\text { menemui } \\
\text { sesuatu yang } \\
\text { baru }\end{array}$ & $\begin{array}{l}\text { pelajari sesuatu } \\
\text { secara alami }\end{array}$ & $\begin{array}{l}\text { melibatkan } \\
\text { pembelajaran diri } \\
\text { sendiri }\end{array}$ \\
\hline Pengetahuan & $\begin{array}{l}\text { mendapatilmu } \\
\text { tentang sejarah } \\
\text { arkeologi }\end{array}$ & $\begin{array}{l}\text { Pengungkapan } \\
\text { fakta terhadap } \\
\text { ilmu sejarah }\end{array}$ & $\begin{array}{l}\text { memperolehbanyak } \\
\text { pengetahuan } \\
\text { tentang sejarah } \\
\text { Malaysia }\end{array}$ & $\begin{array}{l}\text { membantupelajari } \\
\text { ilmu sejarah }\end{array}$ \\
\hline $\begin{array}{l}\text { Efek Program } \\
\text { Setualangan }\end{array}$ & $\begin{array}{l}\text { sangat efektif, } \\
\text { ingin mengikut } \\
\text { lagi dan, } \\
\text { berterima kasih } \\
\text { pada } \\
\text { penyelenggara }\end{array}$ & $\begin{array}{l}\text { Menarik, sesuai } \\
\text { untuk ikut serta }\end{array}$ & Sangat layak & $\begin{array}{l}\text { Lebih bagus jika } \\
\text { ada ekskavasi } \\
\text { sendiri, lebih bisa } \\
\text { merasakan dan } \\
\text { memahami. }\end{array}$ \\
\hline $\begin{array}{l}\text { Perasaan } \\
\text { Setelah sertai } \\
\begin{array}{l}\text { Penelitian } \\
\text { Lapangan }\end{array}\end{array}$ & $\begin{array}{l}\text { Merasa senang } \\
\text { dan gembira }\end{array}$ & $\begin{array}{l}\text { Bagus juga } \\
\text { sekali-kali } \\
\text { keluar belajar } \\
\text { bersama teman } \\
\text { teman }\end{array}$ & $\begin{array}{l}\text { Harus mengikuti } \\
\text { lagi jika ada } \\
\text { program seperti ini }\end{array}$ & $\begin{array}{l}\text { harap dapat turut } \\
\text { serta dalam sesi } \\
\text { berikutnya }\end{array}$ \\
\hline
\end{tabular}

Berdasarkan hasil wawancara dalam Tabel 3, menunjukkan berbagai reaksi dalam kalangan guru-guru sejarah yang telah menyertai Program Petualangan Sejarah. Apabila pertanyaan tentang kegunaan penelitian 
lapangan, masing-masing mempunyai pendapat tersendiri dan masing-masing memahami konsep penelitian lapangan. Sewaktu ada pertanyaan penelitian lapangan dapat membantu meningkatkan pengetahuan sejarah, keempat-empat peserta akui dan menyatakan berlakunya sesuatu ilmu pembelajaran dalam diri individu peserta. Perkataan ïlmu berulang pada setiap kali peserta menjawab. Apabila ditanya tentang efek Program Petualangan Sejarah responnya adalah sangat mendorong. Mereka rasa agak layak menyertai program ini, minat yang ada pada mereka menunjukkan rasa ingin turut serta sekiranya penyelenggara adakan penelitian tahap kedua. Namunada seorang peserta meluapkan perasaan bahwa jika diberi peluang untuk merasakan teknik ekskavasi atau penggalian batu di_Sungai Batu mungkin akan lebih menyenangkan. Pada akhirnya pertanyaan mengenai perasaan peserta setelah mengikuti program penelitian lapangan rata-rata menunjukkan tingkat kebahagiaan yang tinggi, ingin turut serta dalam program-program yang akan datang.

\section{Implikasi penelitian}

Penelitian kasus ini memberi suatu gambaran jelas bahwa metode penelitian lapangan mempunyai potensi tinggi dalam meningkatkan kemahiran pedagogi guru sejarah. Ini terbukti dengan pernyataan-pernyataan yang dibagikan oleh para peserta program Petualangan Sejarah. Guru-guru Sejarah secara keseluruhan menunjukkan minat dan semangat yang kuat sepanjang perjalanan program Petualangan Sejarah. Malah hasil penelitian ini membuka peluang kepada peserta penelitian untuk berbagi ide sesama guru-guru Sejarah daerah Seberang Perai dan responden juga telah menunjukkan semangat kerja sama kelompok yang positif. Hasil persembahan yang dipresentasikan secara berkelompok mempunyai nilai dan ilmu sejarah memandangkan terdapatnya kolaborasi sesama guruguru Sejarah. Pada masa yang sama pendekatan ini mampu menjana ilmu kognitif yang tinggi dalam kalangan guru-guru Sejarah. Program Petualangan Sejarah juga telah membekalkan ilmu pengetahuan mengenai Sejarah arkeologi Lembah Bujang dan Sungai Batu kepada guru-guru sejarah. Responden juga berpeluang menjalani penelitian lapangan serta mempelajari proses dan prosedur untuk pelaksanaan penelitian lapangan pada masa akan datang. Guru Sejarah memperoleh keyakinan dalam diri untuk menganjur atau mengurus penelitian-penelitian lapangan atau program-program petualangan Sejarah sebagaimana yang dianjurkan. Tidak dapat ditolak bahwa 
penelitian lapangan memberi peluang untuk guru mengamati, menyelami dan mempraktekan pengajaran di_dalam kelas ke dunia nyata. Oleh hal yang demikian, guru Sejarah dapat menghayati dan memahami topik-topik Sejarah dengan mudah. Pengajaran melalui metode lapangan dapat meningkatkan minatpembelajaran murid dan tidak hanya dengan bahan bacaan semata, lebih dari itu murid dapat membuka pikiran dan membuat generalisasi serta mengaitkan pembelajaran tersebut dengan dunia nyata. Justru metode ini adalah sesuai sejalan dengan pengajaran dan pembelajaran abad ke-21. Semoga gurugurusejarah dapat mempraktekan metode tersebut bagi pelajaranpelajaran Sejarah dimasa akan datang.

\section{KESIMPULAN}

Penelitian ini bertujuan untuk menilai efektivitas penelitian lapangan dalam meningkatkan keterampilan pedagogi guru sejarah dalam kalangan guru-guru Sejarah Sekolah Menengah. Penelitian ini juga dapat menggambarkan betapa senangnya guruguru bergabung dengan penelitian lapangan dan mempelajari sedikit banyak tentang sejarah situs arkeologi di Malaysia. Semoga pengetahuan ini dapat meningkatkan keterampilan pedagogi Sejarah saat ini. Penelitian Lapangan juga dapat memupuk nilai dan penghayatan Sejarah dalam kalangan guru-guru Sejarah. Memandangkan penyelidikan arkeologi konservasi masih baru di_negara ini, penelitian lapangan juga memberi jalan kepada para guru untuk meneruskan penelitian terhadap penemuan-penemuan baru ini agar dapat dipelihara dan dilestarikan bagi mempertahankan warisan sejarah di_negara kita.

\section{Daftar Pustaka}

Boyle, A. et al. (2007). Fieldwork is Good: the Student Perception and the Affective Domain, Journal of Geography in Higher Education, 31:2, 299-317, DOI: $10.1080 / 03098260601063628$

Neuman W.L. (2003). Social Research Methods (Qualitative and Quantitative Approaches), Ed. 5th. (Boston: Allyn and Bacon, 2003), hlm. 363.

Kementerian Pendidikan Malaysia. (2014). Dokumen Standar Kurikulum dan Pentaksiran.Kuala Lumpur.

Khoo Kay Kim, (2000). Falsafah Sejarah: Ke arah Mengembangkan Unsur Patriotisme dan Kenegaraan. Kertas kerja yang dibentangkan di Seminar Kebangsaan Falsafah Pendidikan Ke arah Pemantapan Gagasan dan Wawasan Kenegaraan 6-7 Julai. Universiti Malaya, Kuala Lumpur.

Noria Munirah Yakub dan Anuar bin Ahmad, (2016). Kemahiran Pemikiran Sejarah (KPS) Dalam Kalangan Bakal Guru di_Institut 
Pengajian Tinggi (IPTA). Fakulti Pendidikan. Universiti Kebangsaan Malaysia (UKM), Bangi.

Subadrah Nair dan Malar Muthiah, (2005). Penggunaan Model Konstruktivisme Lima Fasa Needham dalam Pembelajaran Sejarah. Jurnal Pendidik dan Pendidikan. Jil.20: 20-24, Universiti Sains Malaysia, Pulau Pinang.

Abdul Samad Hadi, (1995). Panduan Kajilidikan Geografi: Bangi: UKM.

Wan Ruslan, Narimah Samat dan Nooriah Yusof, (2014). Kerja Luar: Teknik, Prosedur dan Aplikasi dalam Geografi. Penerbit USM. 
Kajian Lapangan Meningkatkan Kemahiran Pedagogi Guru Sejarah ..., Punitha Muniandy, 1-14 